\title{
Tribocorrosion Properties of NiCrAlY Coating in Different Corrosive Environments
}

\author{
Bo Li ${ }^{1, * \mathbb{C}}$, Yimin Gao ${ }^{1}$, Cong $\mathrm{Li}^{1}{ }^{1, *}$, Hongjian Guo ${ }^{2}$, Qiaoling Zheng ${ }^{1}$, Yefei $\mathrm{Li}^{1}$, \\ Yunchuan Kang ${ }^{1}$ and Siyong Zhao ${ }^{3}$ \\ 1 State Key Laboratory for Mechanical Behaviour of Materials, School of Materials Science and Engineering, \\ Xi'an Jiaotong University, Xi'an 710049, China; ymgao@xjtu.edu.cn (Y.G.); zhengql@mail.xjtu.edu.cn (Q.Z.); \\ yefeili@126.com (Y.L.); kangyc30@stu.xjtu.edu.cn (Y.K.) \\ 2 School of Bailie Mechanical Engineering, Lanzhou City University, Lanzhou 730070, China; \\ chinaghj2019@hotmail.com \\ 3 Guangxi Great Wall Machineries, Hezhou 542800, China; wei9786@163.com \\ * Correspondence: libo616@mail.xjtu.edu.cn (B.L.); licong369@stu.xjtu.edu.cn (C.L.)
}

Received: 2 February 2020; Accepted: 3 April 2020; Published: 16 April 2020

\begin{abstract}
Atmospheric plasma spraying (APS) was taken to fabricate the NiCrAlY coating. The corrosion-wear properties of NiCrAlY coating was measured respectively under deionized water, artificial seawater, $\mathrm{NaOH}$ solution and $\mathrm{HCl}$ solution. Experimental results presented that the as-sprayed $\mathrm{NiCrAlY}$ coating consisted of $\mathrm{Ni}_{3} \mathrm{Al}$, nickel-based solid solution, $\mathrm{NiAl}$ and $\mathrm{Y}_{2} \mathrm{O}_{3}$. In deionized water, the coating with the lowest corrosion current density $\left(i_{\text {corr }}\right)$ of $7.865 \times 10^{-8} \mathrm{~A} / \mathrm{cm}^{2}$ was hard to erode. Meanwhile, it presented a lower friction coefficient and the lowest wear rate. In $\mathrm{HCl}$ solution, NiCrAlY coating gave the highest corrosion current density $\left(i_{\text {corr }}\right)$ of $3.356 \times 10^{-6} \mathrm{~A} / \mathrm{cm}^{2}$ and a higher wear rate of $6.36 \times 10^{-6} \mathrm{~mm}^{3} / \mathrm{Nm}$. Meanwhile, the emergence of $\mathrm{Al}(\mathrm{OH})_{3}$ on the coating surface could reduce the direct contact between the counter ball and sample effectively, which was conducive to the lowest friction coefficient of 0.24 .
\end{abstract}

Keywords: corrosion-wear performance; dense structure; corrosion potential; corrosion rate; worn surface

\section{Introduction}

In engineering fields, wear often occurs under different corrosive circumstances leading to the degradation rate of engineering parts [1]. For instance, some mechanical parts utilized in the marine atmosphere, pulping and mining, suffer the collaborative destruction of corrosion and wear [2-6]. Meanwhile, the synergism of corrosion and wear decreases the service life of the material. In the process of friction, the passive film on the worn surface could be destroyed by friction force and the new passive film is hard to form, which would make the material suffering more serious damage. Normally, the corrosion-wear material loss is greater than the sum of corrosion and wear. Therefore, it is very imperative to improve the corrosion-wear resistance property of mechanical parts in different corrosive environments. To meet this requirement, the protective coatings are applied to protect the mechanical parts without changing the external structure. MCrAlY $(\mathrm{M}=$ Cobalt and/or Nickel) alloys with excellent oxidation resistance, corrosion resistance and wear resistance performance have been widely used in nuclear power, automotive and marine industries acting as the protective coatings [1,7-15]. J. Chen et al. investigated the tribocorrosion behavior of NiCoCrAlYTa coating in corrosion. The results showed that this kind of coating presented an extremely dense structural characteristic and excellent tribological performance in $\mathrm{NaOH}$ and $\mathrm{HCl}$ solutions [1]. $\mathrm{M}$. Marcu et al. studied the microstructure and oxidation resistance of as-sprayed $\mathrm{NiCrAlY} / \mathrm{Al}_{2} \mathrm{O}_{3}$ coating. The results 
presented that the as-sprayed $\mathrm{NiCrAlY} / \mathrm{Al}_{2} \mathrm{O}_{3}$ coating has the best cyclic oxidation resistance with an oxidation rate of $2.62 \times 10^{-12} \mathrm{~g}^{2} \cdot \mathrm{cm}^{-4} \cdot \mathrm{s}^{-1}$ at high temperature and good adhesion during the cyclic oxidization treatment [8]. Current researches mainly focus on the oxidation resistance, corrosion, mechanical and tribological performance of the coatings [16-22]. These materials are also used for reciprocating parts in corrosive environments [23], so the research of the wear-corrosion resistance is still important in the process of sliding. However, few researches pay attention to the synergy of corrosion and wear [24], and its mechanism is still unclear.

In this work, the tribocorrosion properties of NiCrAlY coating were studied and the synergistic mechanisms between wear and corrosion in different corrosive environments were discussed in detail. The objective of this paper is to research how corrosive environments affect the tribological behavior of NiCrAlY coating and the interaction degree between corrosion and wear. This research would provide usable direction to the NiCrAlY coating application in corrosive environments.

\section{Materials and Methods}

\subsection{Coating Preparation}

Gas atomized spherical $\mathrm{Ni}_{22} \mathrm{Cr}_{10} \mathrm{Al}_{1.0} \mathrm{Y}$ (wt.\%) powder (53-106 $\mu \mathrm{m}$ ) was bought from Sulzer Metco (Winterthur, Switzerland). The NiCrAlY coating was prepared by atmospheric plasma spraying (APS). The Inconel 718 alloy was sand-blasted, then ultrasonically cleaned with ethanol before spraying. The coating thickness was about $300 \mu \mathrm{m}$. The specific spraying parameters presented were: flow rate of Ar was $40 \mathrm{~L} / \mathrm{min}$; flow rate of $\mathrm{H}_{2}$ was $5 \mathrm{~L} / \mathrm{min}$; spraying angle was $90^{\circ}$; feed rate of the powder was $42 \mathrm{~g} / \mathrm{min}$; voltage was $60 \mathrm{~V}$; the current was $500 \mathrm{~A}$ and spray distance was $110 \mathrm{~mm}$.

\subsection{Characterization}

The micromorphologies of cross-section and worn surface of this coating were measured by field emission scanning electron microscopy (FE-SEM, Tescan Mira 3, Bron, Kohoutovice, Czech Republic). A Philips X'Pert-MRD X-ray diffractometer (XRD; Cu- $\mathrm{K}_{\mathrm{a}}$ radiation, current $150 \mathrm{~mA}$, potential $40 \mathrm{kV}$, Philips, Eindhoven, The Netherlands) was utilized to analyzed phase composition. The phase compositions on the worn surface were analyzed by Czemy-Tumer Labram HR800 Raman spectrometer (Horiba, Paris, France).

\subsection{Tribocorrosion Tests}

The tribocorrosion experiments were tested in deionized water $(\mathrm{pH}=7)$, artificial seawater $(\mathrm{pH}=8.2), 0.1 \mathrm{M} \mathrm{NaOH}$ solution $(\mathrm{pH}=13)$ and $0.1 \mathrm{M} \mathrm{HCl}$ solution $(\mathrm{pH}=1)$, with reciprocating ball-on-disk tribometer (UMT, Karlsruhe, Germany). The schematic diagram is shown in Figure 1. The polytetrafluoroethylene (PTFE) does not corrode as it is chemically inert to corrosion. So it acted as the solution cell material. The $\mathrm{Al}_{2} \mathrm{O}_{3}$ ceramic ball acted as the counter ball, whose diameter was $5 \mathrm{~mm}$. Before the friction experiment, the surface of the coating was burnished till the roughness close to $0.5 \mu \mathrm{m}$. The tests were performed at the conditions below: room temperature, $5 \mathrm{~N}$ normal load, $0.8 \mathrm{~mm} / \mathrm{s}$ sliding speed, $3.5 \mathrm{~mm}$ amplitude and $60 \mathrm{~min}$ duration. Repeated experiments were tested in every corrosive environments. The color 3D laser scanning microscope (VK-9710, Keyence, Osaka, Japan) and SEM were utilized to analyze the worn surface. The wear rate was got by $\mathrm{W}=\mathrm{V} / \mathrm{LF}$, where W represented the wear rate $\left(\mathrm{mm}^{3} / \mathrm{Nm}\right), \mathrm{V}$ represented the wear volume loss $\left(\mathrm{mm}^{3}\right)$, L represented the sliding distance $(\mathrm{m})$ and $\mathrm{F}$ represented the load $(\mathrm{N})$. 


\section{Load}

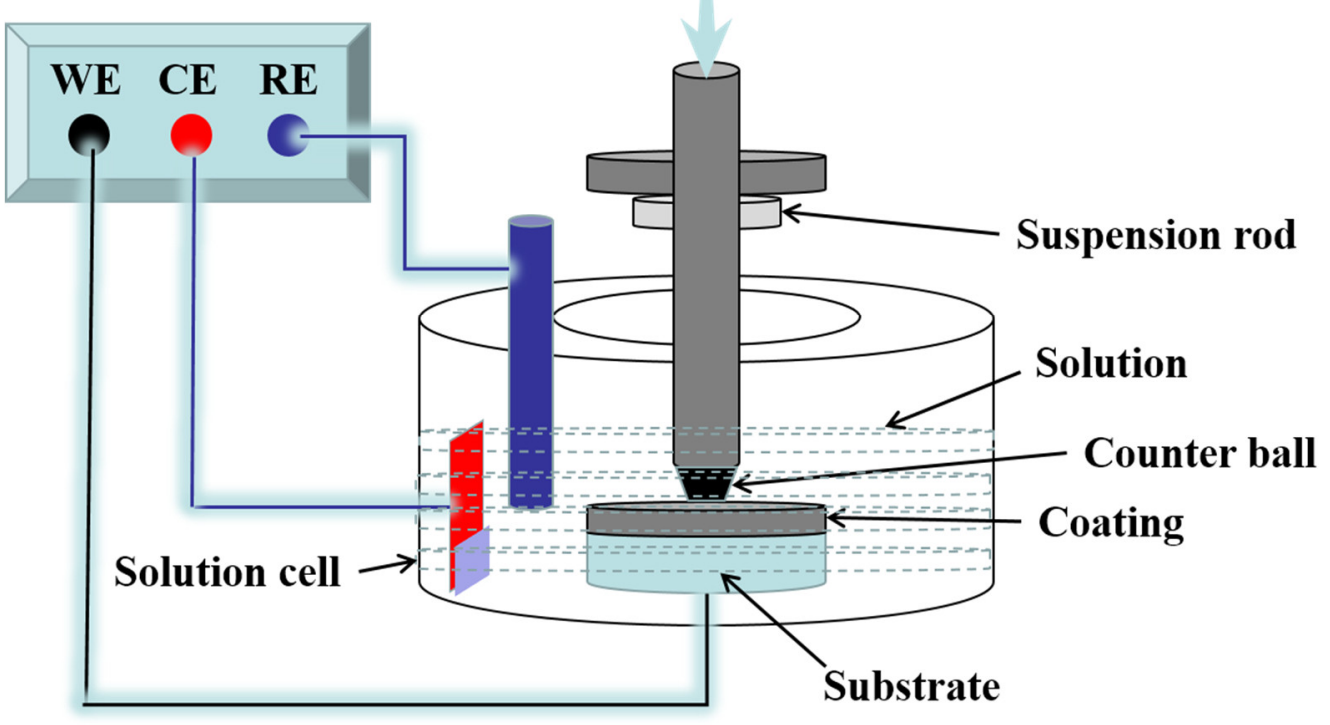

Figure 1. Reciprocating ball-on-disc tribometer schematic diagram.

\section{Results and Discussions}

\subsection{Morphology and Composition of Powders and NiCrAlY Coating}

Figure 2 presents the SEM micromorphology and XRD pattern of NiCrAlY powder. The spherical shape powder with a size of 53-106 $\mu \mathrm{m}$ (Figure 2a) exhibits satisfactory flowability and thus it is very beneficial to the feeding rate in the process of spraying [25]. The results of the XRD pattern show that the NiCrAlY powder composes of $\mathrm{Ni}_{3} \mathrm{Al}, \mathrm{NiAl}$ and nickel-based solid solution and has high crystallinity (Figure 2b).
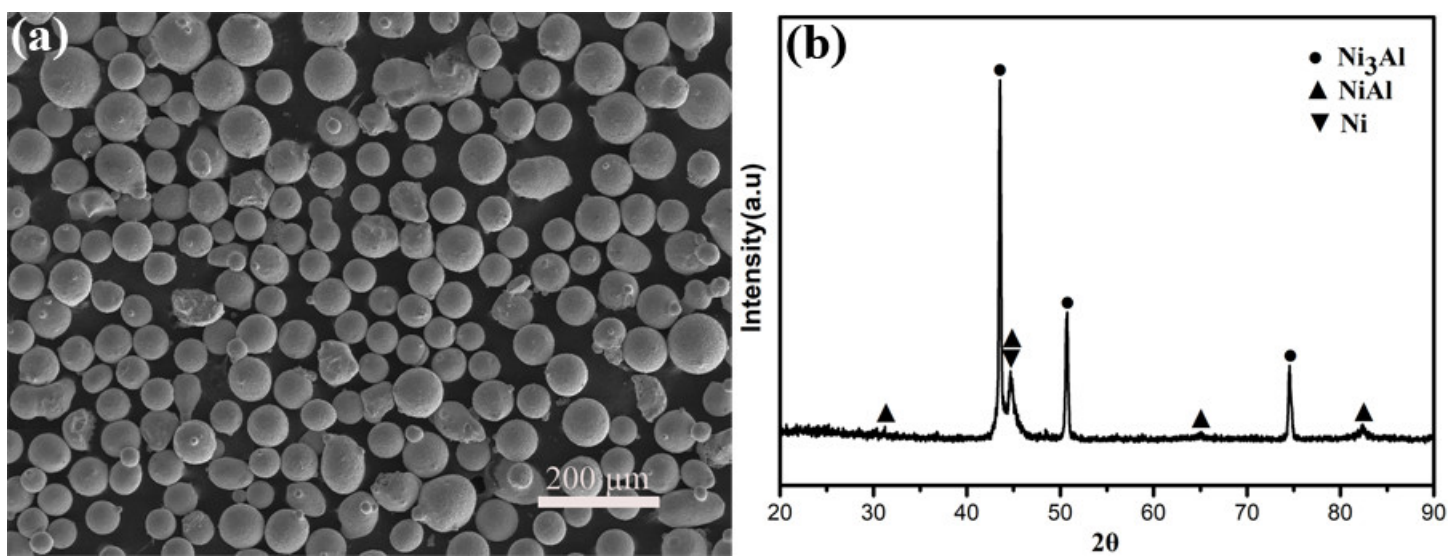

Figure 2. SEM micromorphology (a) and XRD pattern (b) of NiCrAlY powder.

Figure 3 presents the SEM morphology of the cross-section and diffraction pattern of NiCrAlY coating. The coating contains some cracks and pores. Meanwhile, every phase combines well and between any two phases have no evident cracks (Figure 3a). Compared with the NiCrAlY powder (Figure 3b), a new phase of $\mathrm{Y}_{2} \mathrm{O}_{3}$ formed on the coating, which could obviously increase the microhardness and strength [26]. 

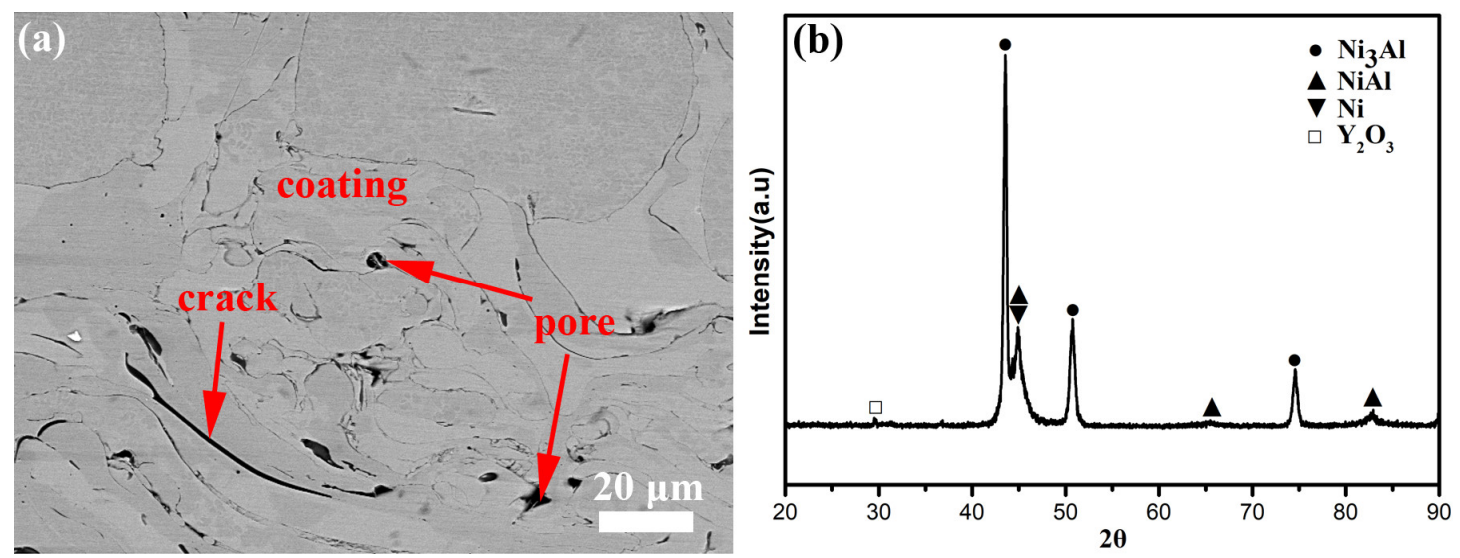

Figure 3. SEM morphology of (a) cross-section and (b) XRD pattern of NiCrAlY coating.

\subsection{Electrochemical Performance of NiCrAlY Coating}

Figure 4 gives the potentiodynamic polarization curves of NiCrAlY coating sliding conditions in different corrosive solutions. Key test parameters such as the corrosion potential $\left(E_{\text {corr }}\right)$, corrosion current density $\left(i_{\text {corr }}\right)$, anodic and cathodic Tafel slopes $\left(\beta_{a}\right.$ and $\left.\beta_{c}\right)$ are obtained from Figure 4 and shown in Table 1 . The polarization resistance value $\left(R_{p}\right)$ is calculated by Stern-Geary equation:

$$
R_{p}=\frac{\beta_{a} \times \beta_{c}}{2.303 i_{\text {corr }}\left(\beta_{a}+\beta_{c}\right)} .
$$

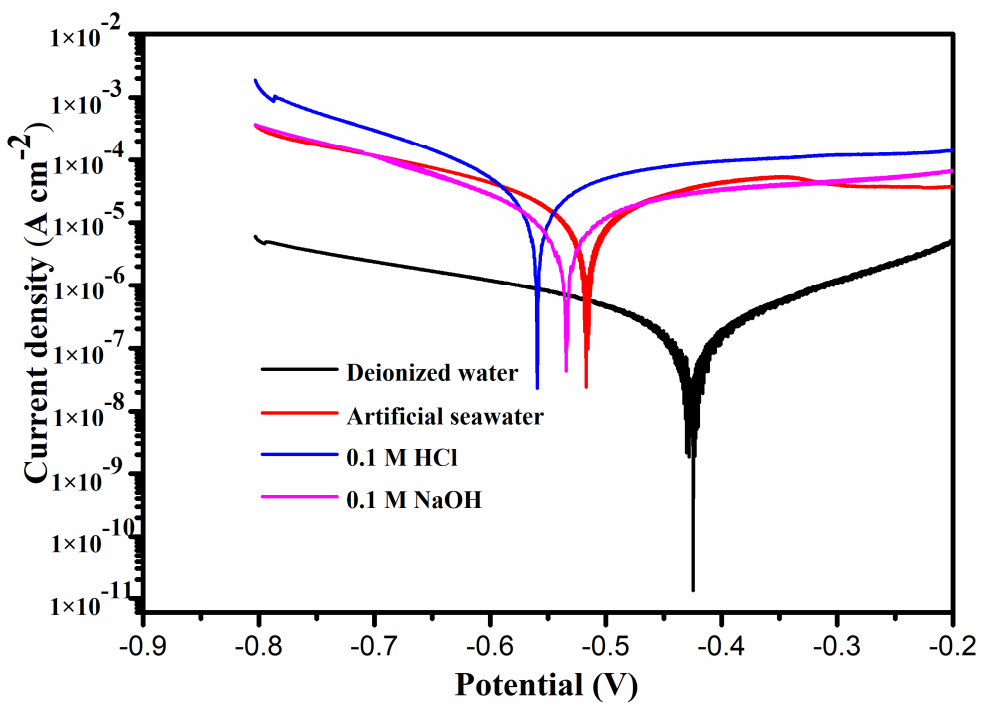

Figure 4. Potentiodynamic polarization curves of NiCrAlY coating sliding conditions in different corrosive solutions.

Results indicate that the corrosion potential $\left(E_{c o r r}\right)$ of NiCrAlY coating under deionized water is the highest of $-0.428 \mathrm{~V}$ (vs. SCE). However, the $E_{\text {corr }}$ of the coating in artificial seawater, $\mathrm{HCl}$ and $\mathrm{NaOH}$ shift to $-0.516 \mathrm{~V}$ (vs. SCE), $-0.559 \mathrm{~V}$ (vs. SCE) and $-0.535 \mathrm{~V}$ (vs. SCE) respectively. Simultaneously, the corrosion current density $\left(i_{\text {corr }}\right)$ of this coating in deionized water shows the lowest of $7.865 \times 10^{-8} \mathrm{~A} / \mathrm{cm}^{2}$. Generally speaking, corrosion current density, whose rate is often used as corrosion rate, is a crucial reference to evaluate corrosion resistance [13,27]. Therefore, the coating under deionized water with the lowest corrosion rate is hard to corrode. The coating in $\mathrm{HCl}$ presenting the highest corrosion current density is very easy to be corroded. At the same time, the coating in 
deionized water has the highest $\beta_{a}, \beta_{c}$ and $R_{p}$ of $0.072 \mathrm{~V} / \mathrm{dec}, 0.049 \mathrm{~V} / \mathrm{dec}$ and $1.610 \times 10^{5} \Omega$ respectively, which further illustrates that the coating in deionized water holds a good corrosion resistance.

Table 1. Corrosion parameters of NiCrAlY coating from potentiodynamic polarization curves.

\begin{tabular}{cccccc}
\hline $\begin{array}{c}\text { Corrosive } \\
\text { Solutions }\end{array}$ & $\boldsymbol{E}_{\text {corr }}(\mathrm{V}, \mathbf{v s .} \mathrm{SCE})$ & $\boldsymbol{i}_{\text {corr }}\left(\mathrm{A} / \mathbf{c m}^{\mathbf{2}}\right)$ & $\boldsymbol{\beta}_{\boldsymbol{a}}(\mathrm{V} / \mathbf{d e c})$ & $-\boldsymbol{\beta}_{\boldsymbol{c}}(\mathrm{V} / \mathbf{d e c})$ & $\boldsymbol{R}_{\boldsymbol{p}}(\boldsymbol{\Omega})$ \\
\hline Deionized water & -0.428 & $7.865 \times 10^{-8}$ & 0.072 & 0.049 & $1.610 \times 10^{5}$ \\
Artificial seawater & -0.516 & $8.986 \times 10^{-7}$ & 0.043 & 0.042 & $1.027 \times 10^{4}$ \\
$0.1 \mathrm{M} \mathrm{HCl}$ & -0.559 & $3.356 \times 10^{-6}$ & 0.036 & 0.039 & $2.422 \times 10^{3}$ \\
$0.1 \mathrm{M} \mathrm{NaOH}$ & -0.535 & $1.039 \times 10^{-6}$ & 0.039 & 0.038 & $8.044 \times 10^{3}$ \\
\hline
\end{tabular}

\subsection{Tribological Behavior of NiCrAlY Coating}

Figure 5 shows the friction curves and wear rate of NiCrAlY coating in different corrosive solutions. The friction coefficient (COF) of the coating under the $\mathrm{NaOH}$ solution was the highest, with a value of 0.46. In artificial seawater and deionized water, it was 0.37 and 0.26 , respectively. Surprisingly, the COF reduced to 0.24 and remains steady in $\mathrm{HCl}$ solution. Nevertheless, the NiCrAlY coating has a high wear rate (WR) of $6.36 \times 10^{-6} \mathrm{~mm}^{3} / \mathrm{Nm}$ in the $\mathrm{HCl}$ solution. This phenomenon is likely to show the high corrosion rate of coating in $\mathrm{HCl}$ solution (Figure 4). The synergistic effect of corrosion and wear in a corrosive environment leads to the loss of large material, which usually larger than the synergistic effect of the sum of corrosion and wear [28,29]. So, the coating under the $\mathrm{HCl}$ solution presents a more obvious wear rate. The coating in the $\mathrm{NaOH}$ solution has the highest wear rate of $6.89 \times 10^{-6} \mathrm{~mm}^{3} / \mathrm{Nm}$. At the same time, the coating in deionized water gives the lowest WR of $2.36 \times 10^{-6} \mathrm{~mm}^{3} / \mathrm{Nm}$, which is caused by the lowest corrosion rate of coating in deionized water (Figure 4).
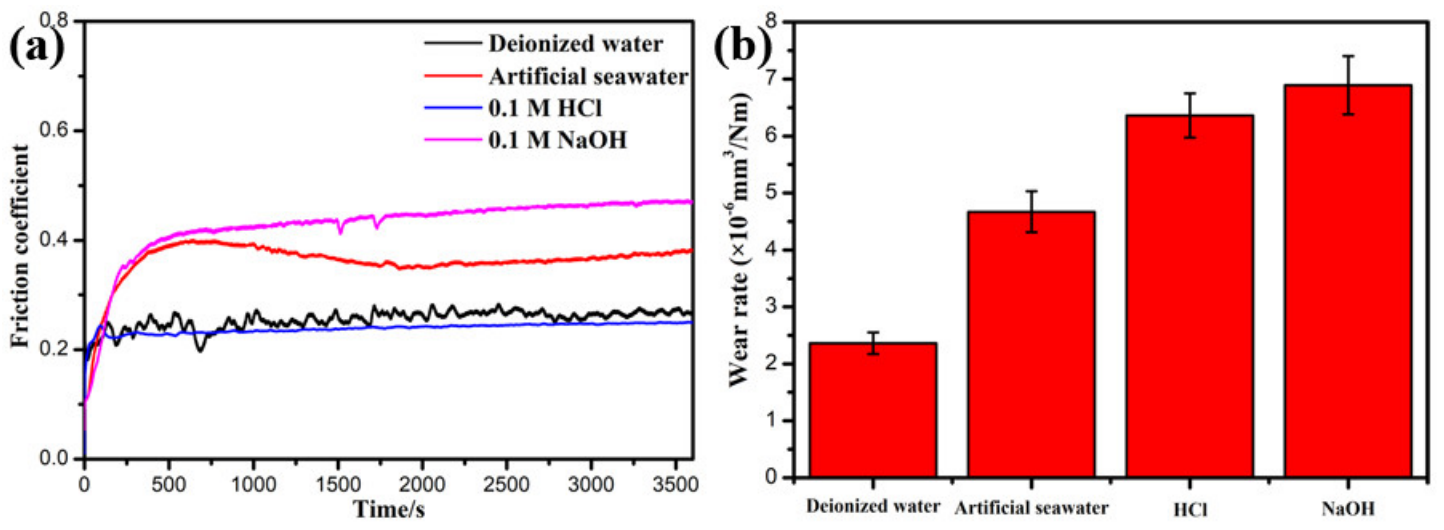

Figure 5. Friction curves (a) and wear rate (b) of NiCrAlY coating in different corrosive solutions.

Figure 6 presents the 2D and 3D configurations of NiCrAlY coating worn surfaces in different corrosive solutions. The worn surface has the shallowest and narrowest friction trace in deionized water (Figure 6a,e). Therefore, the COF and WR are lower (Figure 5). It further illustrates that the coating in deionized water shows excellent corrosion and wear resistance. The worn surface of $\mathrm{NiCrAlY}$ coating in $\mathrm{HCl}$ corrosive solution is very rough and has serious corrosion (Figure 6c). So, the coating obtains high WR under $\mathrm{HCl}$ corrosive solution (Figure 5). The worn track of NiCrAlY coating in $\mathrm{NaOH}$ corrosive solution is the deepest and widest (Figure $6 \mathrm{~d}, \mathrm{f}$ ). Therefore, this coating has the worst tribological performance (Figure 5). 

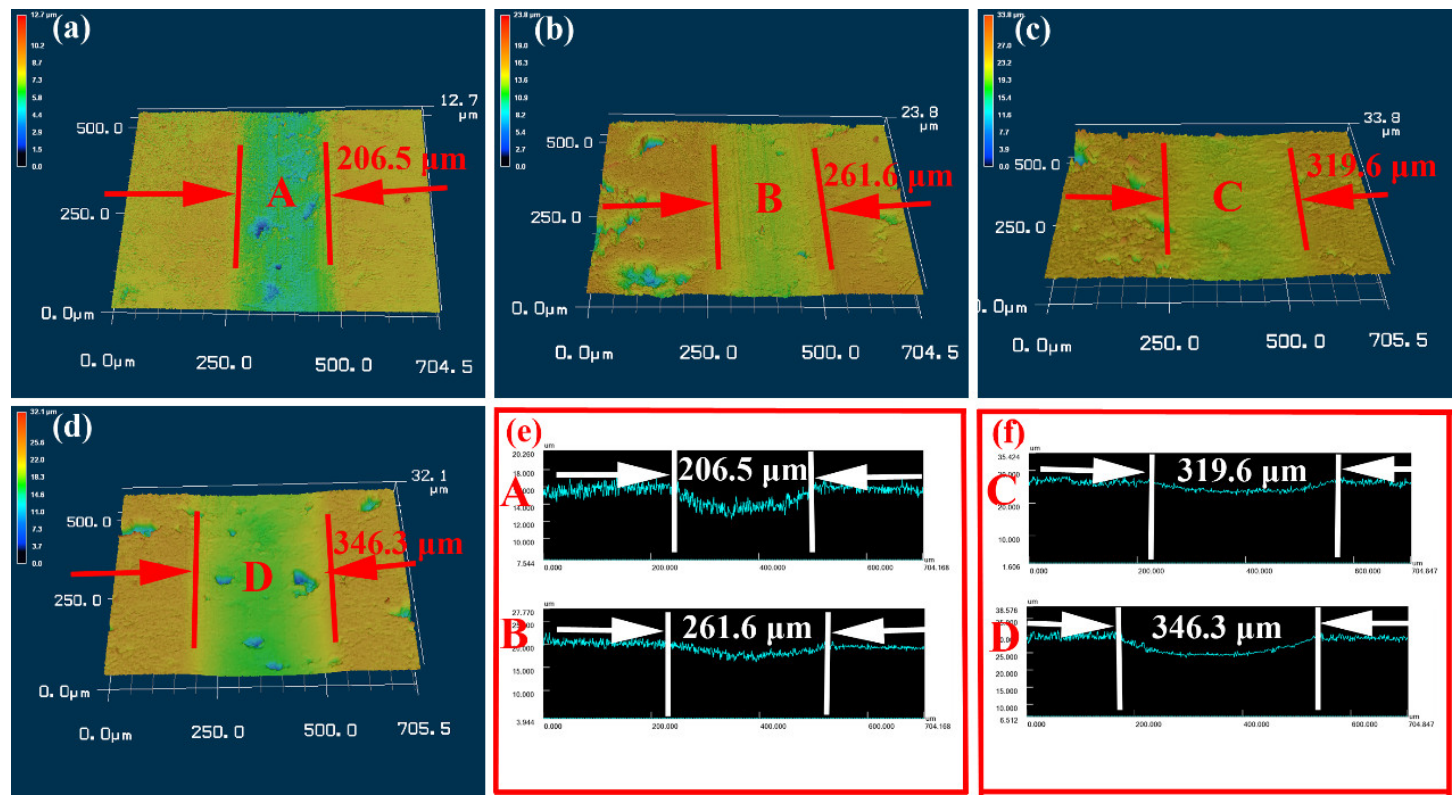

Figure 6. 2D and 3D configurations of NiCrAlY coating worn surfaces in different corrosive solutions: (a) deionized water, (b) artificial seawater, (c) $\mathrm{HCl}$ solution and (d) $\mathrm{NaOH}$ solution; (e) 2D profiles of A and $\mathrm{B}$ regions; (f) $2 \mathrm{D}$ profiles of $\mathrm{C}$ and $\mathrm{D}$ regions.

To further research the influence of corrosive solution upon the corrosion-wear property of NiCrAlY coating, Raman analysis is tested. Figure 7 shows the Raman spectra of the worn surface of NiCrAlY coating in different corrosive solutions. The $\mathrm{Al}_{2} \mathrm{O}_{3}, \mathrm{Cr}_{2} \mathrm{O}_{3}$ and $\mathrm{NiO}$ are the main phases on the worn surface of NiCrAlY coating after sliding in deionized water, artificial seawater and $\mathrm{NaOH}$ solution. Nevertheless, the worn surface of NiCrAlY coating observes the new phase of $\mathrm{Al}(\mathrm{OH})_{3}$ after sliding in $\mathrm{HCl}$ corrosive solution [30]. The results indicate that the NiCrAlY coating has suffered serious corrosion in the $\mathrm{HCl}$ corrosive solution because of the existence of stronger and more numerous peaks [1]. The corrosion products are easily worn out during the friction process. So the wear rate of the coating under $\mathrm{HCl}$ solution is very high (Figure 5).

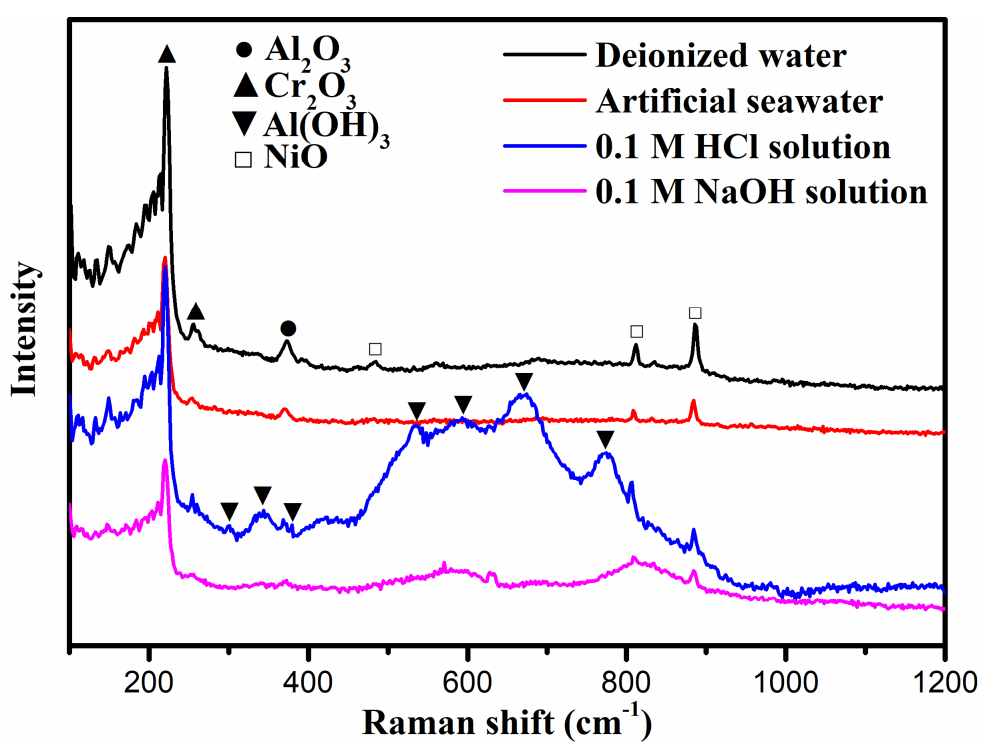

Figure 7. Raman spectra of worn surface of NiCrAlY coating in different corrosive solutions. 


\subsection{Lubrication Behavior of $\mathrm{Al}(\mathrm{OH})_{3}$ on $\mathrm{NiCrAlY}$ Coating in $\mathrm{HCl}$ Solution}

Figure 8 shows the corrosion-wear mechanisms of NiCrAlY coating in the $\mathrm{HCl}$ solution. The surface becomes very smooth because the corrosion-wear effect with the mix of oxides and hydroxides formed by electrochemical reactions (Figures 6 and 7). In terms of the potential values, aluminum is the least noble element and the order of potentials follows $\mathrm{Ni}>\mathrm{Cr}>\mathrm{Al}$ [1]. So the aluminum element is more likely to be corroded at first. The following electrochemical reactions could explain the process of $\mathrm{Al}(\mathrm{OH})_{3}$ formation:

$$
\begin{gathered}
\mathrm{Al} \rightarrow \mathrm{Al}^{+}+3 \mathrm{e}^{-} \\
2 \mathrm{H}^{+}+2 \mathrm{e}^{-} \rightarrow \mathrm{H}_{2} \\
\mathrm{H}_{2} \mathrm{O}+2 \mathrm{e}^{-} \rightarrow \mathrm{H}_{2}+2 \mathrm{OH}^{-} \\
\mathrm{Al}^{+}+3 \mathrm{OH}^{-} \rightarrow \mathrm{Al}(\mathrm{OH})_{3}
\end{gathered}
$$
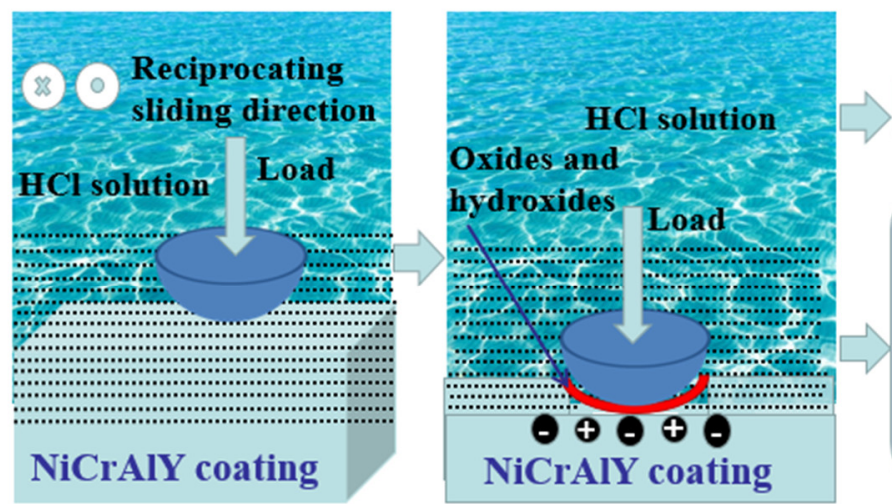

$$
\mathrm{AlO}_{2}{ }^{-}+\mathrm{H}^{+}+\mathrm{H}_{2} \mathrm{O} \rightarrow \mathrm{Al}(\mathrm{OH})_{3}
$$

$$
\begin{aligned}
& \mathrm{Al} \rightarrow \mathrm{Al}^{3+}+3 \mathrm{e}^{-} \\
& 2 \mathrm{H}^{+}+2 \mathrm{e}^{-} \rightarrow \mathrm{H}_{2} \\
& \mathrm{H}_{2} \mathrm{O}+2 \mathrm{e}^{-} \rightarrow \mathrm{H}_{2}+2 \mathrm{OH}^{-} \\
& \mathrm{Al}^{3+}+3 \mathrm{OH}^{-} \rightarrow \mathrm{Al}(0 \mathrm{H})_{3} \\
& \mathrm{Al}^{3+}+4 \mathrm{OH}^{-} \rightarrow 2 \mathrm{H}_{2} \mathrm{O}+\mathrm{AlO}_{2}^{-} \\
& 2 \mathrm{Cr}+3 \mathrm{H}_{2} \mathrm{O} \rightarrow \mathrm{Cr}_{2} \mathrm{O}_{3}+6 \mathrm{H}^{+}+6 \mathrm{e}^{-}
\end{aligned}
$$

\section{Corrosion-wear}

Figure 8. Schematic diagram of corrosion-wear mechanisms of NiCrAlY coating in $\mathrm{HCl}$ solution.

Terryn et al. [31] illustrated that the generation of $\mathrm{Al}(\mathrm{OH})_{3}$ is related to local $\mathrm{pH}$ changes in the hydrogen reduction region. Hence, the $\mathrm{Al}(\mathrm{OH})_{3}$ could be formed where the hydrogen evolution occurs. Furthermore, when the local $\mathrm{pH}$ rises to above $9, \mathrm{Al}^{3+}$ ions will react with excessive $\mathrm{OH}^{-}$ions and forms aluminate anions [1]. Aluminate anions cannot maintain stable in $\mathrm{HCl}$ corrosive solution and will precipitate as $\mathrm{Al}(\mathrm{OH})_{3}$ (Figure 8). This reaction can be described as follows:

$$
\begin{aligned}
& \mathrm{Al}^{+}+4 \mathrm{OH}^{-} \rightarrow \mathrm{AlO}_{2}{ }^{-}+2 \mathrm{H}_{2} \mathrm{O} \\
& \mathrm{AlO}_{2}{ }^{-}+\mathrm{H}^{+}+\mathrm{H}_{2} \mathrm{O} \rightarrow \mathrm{Al}(\mathrm{OH})_{3}
\end{aligned}
$$

Thus, it inexistences the $\mathrm{Al}(\mathrm{OH})_{3}$ on the worn surface of NiCrAlY coating in $\mathrm{NaOH}$ solution in the process of sliding but the following reaction [32]:

$$
2 \mathrm{Al}+2 \mathrm{OH}^{-}+\mathrm{H}_{2} \mathrm{O} \rightarrow 2 \mathrm{AlO}_{2}^{-}+2 \mathrm{H}_{2}
$$

Of course, in addition to the $\mathrm{Al}$ dissolution, according to the standard of electrode potentials, $\mathrm{Cr}$ element is also dissolved at the anodic cycle and is electrochemically oxidized to $\mathrm{Cr}_{2} \mathrm{O}_{3}$, which is well consistent with the micro-Raman results (Figure 7) [1]. The oxidation reaction process can be illustrated as follows [30]:

$$
2 \mathrm{Cr}+3 \mathrm{H}_{2} \mathrm{O} \rightarrow \mathrm{Cr}_{2} \mathrm{O}_{3}+6 \mathrm{H}^{+}+6 \mathrm{e}^{-}
$$


The above oxidation reactions and metal dissolution explain the smooth surface. $\mathrm{Al}(\mathrm{OH})_{3}$ can be evenly distributed on the smooth worn surface and effectively reduce the direct contact of counter ball and sample. At the same time, the frictional shear stress can form the lubricating layer on the worn surface, which can obviously reduce the friction coefficient of coating in $\mathrm{HCl}$ corrosive solution [1]. Therefore, the COF of NiCrAlY coating in the $\mathrm{HCl}$ corrosive solution is the lowest of 0.24 (Figure 5).

\section{Conclusions}

In this work, the corrosion-wear properties of NiCrAlY coating were studied under deionized water, artificial seawater, $0.1 \mathrm{M} \mathrm{HCl}$ solution and $0.1 \mathrm{M} \mathrm{NaOH}$. The main conclusions are given as follows:

(1) The NiCrAlY coating is composed of $\mathrm{Ni}_{3} \mathrm{Al}$, nickel-based solid solution, $\mathrm{NiAl}$ and $\mathrm{Y}_{2} \mathrm{O}_{3}$.

(2) In deionized water, the NiCrAlY coating with the lowest corrosion current density of $7.865 \times 10^{-8} \mathrm{~A} / \mathrm{cm}^{2}$ is hard to erode. Meanwhile, it presents a lower friction coefficient and the lowest wear rate.

(3) In $\mathrm{HCl}$ corrosive solution, the coating gives the highest corrosion current density $\left(i_{\text {corr }}\right)$ of $3.356 \times 10^{-6} \mathrm{~A} / \mathrm{cm}^{2}$ and a higher wear rate of $6.36 \times 10^{-6} \mathrm{~mm}^{3} / \mathrm{Nm}$.

(4) In $\mathrm{HCl}$ corrosive solution, the emergence of $\mathrm{Al}(\mathrm{OH})_{3}$ on the coating surface could reduce the direct contact between the counter ball and sample effectively, which is conducive to the lowest friction coefficient of 0.24 .

Author Contributions: Data curation, Y.K.; Formal analysis, S.Z.; Project administration, Y.G.; Resources, Q.Z.; Software, Y.L.; Visualization, H.G.; Writing—original draft, B.L.; Writing-review \& editing, C.L. All authors have read and agreed to the published version of the manuscript.

Funding: This research was funded by the National Natural Science Foundation of China (Grant No. 51805408, 51665026), the Natural Science Foundation of Shaanxi Province (Grant No. 2019JQ-283), the China Postdoctoral Science Foundation (Grant No. 2019M653597), the Shaanxi Province Postdoctoral Science Foundation, the Fundamental Research Funds for Central Universities (Grant No. xzy012019010, xtr0118008), the Guangxi Innovation Driven Development Project (Grant No. GUIKEAA18242001) and the Guangdong Province Key Area R\&D Program (Grant No. 2019B010942001).

Conflicts of Interest: The authors declare no conflict of interest.

\section{References}

1. Liu, X.; An, Y.; Li, S.; Zhao, X.; Hou, G.; Zhou, H.; Chen, J. An assessment of tribological performance on NiCoCrAlYTa coating under corrosive environments. Tribol. Int. 2017, 115, 35-44. [CrossRef]

2. Ma, F.; Li, J.; Zeng, Z.; Gao, Y. Structural, mechanical and tribocorrosion behaviour in artificial seawater of CrN/AlN nano-multilayer coatings on F690 steel substrates. Appl. Surf. Sci. 2018, 428, 404-414. [CrossRef]

3. Huttunen-Saarivirta, E.; Kilpi, L.; Hakala, T.J.; Carpen, L.; Ronkainen, H. Tribocorrosion study of martensitic and austenitic stainless steels in $0.01 \mathrm{M} \mathrm{NaCl}$ solution. Tribol. Int. 2016, 95, 358-371. [CrossRef]

4. Wang, C.; Ye, Y.; Guan, X.; Hu, J.; Wang, Y.; Li, J. An analysis of tribological performance on Cr/GLC film coupling with $\mathrm{Si}_{3} \mathrm{~N}_{4}, \mathrm{SiC}, \mathrm{WC}, \mathrm{Al}_{2} \mathrm{O}_{3}$ and $\mathrm{ZrO}_{2}$ in seawater. Tribol. Int. 2016, 96, 77-86. [CrossRef]

5. Liu, X.; An, Y.; Zhao, X.; Li, S.; Deng, W.; Hou, G.; Ye, Y.; Zhou, H.; Chen, J. Hot corrosion behavior of NiCoCrAlYTa coating deposited on Inconel alloy substrate by high velocity oxy-fuel spraying upon exposure to molten $\mathrm{V}_{2} \mathrm{O}_{5}$-containing salts. Corros. Sci. 2016, 112, 696-709. [CrossRef]

6. Meng, Y.; Su, F.; Chen, Y. Nickel/Multi-walled Carbon Nanotube Nanocomposite Synthesized in Supercritical Fluid as Efficient Lubricant Additive for Mineral Oil. Tribol. Lett. 2018, 66, 134. [CrossRef]

7. Pereira, J.; Zambrano, J.; Afonso, C.; Amigo, V. Microstructure and mechanical properties of NiCoCrAlYTa alloy processed by press and sintering route. Mater. Charact. 2015, 101, 159-165. [CrossRef]

8. Anghel, E.; Marcu, M.; Banu, A.; Atkinson, I.; Paraschiv, A.; Petrescu, S. Microstructure and oxidation resistance of a NiCrAlY/ $/ \mathrm{Al}_{2} \mathrm{O}_{3}$-sprayed coating on Ti-19Al-10Nb-V alloy. Ceram. Int. 2016, 42, 12148-12155. [CrossRef] 
9. Bolelli, G.; Candeli, A.; Lusvarghi, L.; Ravaux, A.; Cazes, K.; Denoirjean, A.; Valette, S. Tribology of $\mathrm{NiCrAlY}+\mathrm{Al}_{2} \mathrm{O}_{3}$ composite coatings by plasma spraying with hybrid feeding of dry powder + suspension. Wear 2015, 344-345, 69-85. [CrossRef]

10. Eriksson, R.; Yuan, K.; Li, X.; Peng, R. Corrosion of NiCoCrAlY Coatings and TBC Systems Subjected to Water Vapor and Sodium Sulfate. J. Therm. Spray Technol. 2015, 24, 953-964. [CrossRef]

11. Habib, K.; Damra, M.; Carpio, J.; Cervera, I.; Saura, J. Performance of NiCrAlY Coatings Deposited by Oxyfuel Thermal Spraying in High Temperature Chlorine Environment. J. Mater. Eng. Perform. 2014, 23, 3511-3522. [CrossRef]

12. Li, B.; Gao, Y.; Jia, J.; Han, M.; Guo, H.; Wang, W. Influence of heat treatments on the microstructure as well as mechanical and tribological properties of NiCrAlY-Mo-Ag coatings. J. Alloy. Compd. 2016, 686, 503-510. [CrossRef]

13. Liu, X.; Zhao, X.; An, Y.; Hou, G.; Li, S.; Deng, W.; Zhou, H.; Chen, J. Effects of loads on corrosion-wear synergism of NiCoCrAlYTa coating in artificial seawater. Tribol. Int. 2018, 118, 421-431. [CrossRef]

14. Peng, X.; Jiang, S.; Gong, J.; Sun, X.; Sun, C. Preparation and Hot Corrosion Behavior of a NiCrAlY + AlNiY Composite Coating. J. Mater. Sci. Technol. 2016, 32, 587-592. [CrossRef]

15. Yaghtin, A.; Javadpour, S.; Shariat, M. Hot corrosion of nanostructured CoNiCrAlYSi coatings deposited by high velocity oxy fuel process. J. Alloy. Compd. 2014, 584, 303-307. [CrossRef]

16. Bakhsheshi-Rad, H.; Hamzah, E.; Ismail, A.; Daroonparvar, M.; Yajid, M.; Medraj, M. Preparation and characterization of NiCrAlY/nano-YSZ/PCL composite coatings obtained by combination of atmospheric plasma spraying and dip coating on Mg-Ca alloy. J. Alloy. Compd. 2016, 65, 440-452. [CrossRef]

17. Demian, C.; Denoirjean, A.; Pawlowski, L.; Denoirjean, P.; Ouardi, R. Microstructural investigations of $\mathrm{NiCrAlY}+\mathrm{Y}_{2} \mathrm{O}_{3}$ stabilized $\mathrm{ZrO}_{2}$ cermet coatings deposited by plasma transferred arc (PTA). Surf. Coat. Technol. 2016, 300, 104-109. [CrossRef]

18. Li, B.; Jia, J.; Han, M.; Gao, Y.; Wang, W.; Li, C. Microstructure, mechanical and tribological properties of plasma-sprayed NiCrAlY-Mo-Ag coatings from conventional and nanostructured powders. Surf. Coat. Technol. 2017, 324, 552-559. [CrossRef]

19. Liu, Y.; Hu, X.; Zheng, S.; Zhu, Y.; Wei, H.; Ma, X. Microstructural evolution of the interface between NiCrAlY coating and superalloy during isothermal oxidation. Mater. Des. 2015, 80, 63-69. [CrossRef]

20. Tahari, M.; Shamanian, M.; Salehi, M. Microstructural and morphological evaluation of MCrAlY/YSZ composite produced by mechanical alloying method. J. Alloy. Compd. 2012, 525, 44-52. [CrossRef]

21. Wang, J.; Chen, M.; Yang, L.; Zhu, S.; Wang, F. Comparative study of oxidation and interdiffusion behavior of AIP NiCrAlY and sputtered nanocrystalline coatings on a nickel-based single-crystal superalloy. Corros. Sci. 2015, 98, 530-540. [CrossRef]

22. Chen, J.; Cheng, J.; Zhu, S.; Tan, H.; Qiao, Z.; Yang, J. Tribological Behaviors of Cu/AlMgB ${ }_{14}$ Composite Under Deionized Water and Liquid Paraffin. Tribol. Lett. 2018, 67. [CrossRef]

23. Espallargas, N.; Mischler, S. Tribocorrosion behaviour of overlay welded Ni-Cr 625 alloy in sulphuric and nitric acids: Electrochemical and chemical effects. Tribol. Int. 2010, 43, 1209-1217. [CrossRef]

24. Shan, L.; Wang, Y.; Zhang, Y.; Zhang, Q.; Xue, Q. Tribocorrosion behaviors of PVD CrN coated stainless steel in seawater. Wear 2016, 362-363, 97-104. [CrossRef]

25. Chen, J.; An, Y.; Yang, J.; Zhao, X.; Yan, F.; Zhou, H.; Chen, J. Tribological properties of adaptive NiCrAlY-Ag-Mo coatings prepared by atmospheric plasma spraying. Surf. Coat. Technol. 2013, 235, 521-528. [CrossRef]

26. Cai, B.; Tan, Y.; Tan, H.; Jing, Q.; Zhang, Z. Tribological behavior and mechanism of NiCrBSi- $\mathrm{Y}_{2} \mathrm{O}_{3}$ composite coatings. Trans. Nonferrous Met. Soc. China 2013, 23, 2002-2010. [CrossRef]

27. Zhang, R.; Wang, H.; Xing, X.; Yuan, Z.; Yang, S.; Han, Z.; Yuan, G. Effects of Ni addition on tribocorrosion property of TiCu alloy. Tribol. Int. 2017, 107, 39-47. [CrossRef]

28. Buciumeanu, M.; Bagheri, A.; Souza, J.; Silva, F.; Henriques, B. Tribocorrosion behavior of hot pressed CoCrMo alloys in artificial saliva. Tribol. Int. 2016, 97, 423-430. [CrossRef]

29. Mischler, S. Triboelectrochemical techniques and interpretation methods in tribocorrosion: A comparative evaluation. Tribol. Int. 2008, 41, 573-583. [CrossRef]

30. Huang, E.; Li, A.; Xu, J.; Chen, R.; Yamanaka, T. High-pressure phase transition in $\mathrm{Al}(\mathrm{OH})_{3}$ : Raman and X-ray observations. Geophys. Res. Lett. 1996, 23, 3083-3086. [CrossRef] 
31. Terryn, H.; Vereecken, J.; Thompson, G. The electrograining of aluminium in hydrochloric acid-II. Formation of ETCH products. Corros. Sci. 1991, 32, 73-88. [CrossRef]

32. Wang, Y.; Kong, G.; Che, C. Corrosion behavior of $\mathrm{Zn}-\mathrm{Al}$ alloys in saturated $\mathrm{Ca}(\mathrm{OH})_{2}$ solution. Corros. Sci. 2016, 112, 679-686. [CrossRef]

(C) 2020 by the authors. Licensee MDPI, Basel, Switzerland. This article is an open access article distributed under the terms and conditions of the Creative Commons Attribution (CC BY) license (http://creativecommons.org/licenses/by/4.0/). 